\title{
Late winter and early spring home range and habitat use of the endangered Carolina northern flying squirrel in western North Carolina
}

\author{
W. Mark Ford ${ }^{1, *}$, Christine A. Kelly ${ }^{2}$, Jane L. Rodrigue ${ }^{3}$, Richard H. Odom ${ }^{4}$, \\ Douglas Newcomb ${ }^{5}$, L. Michelle Gilley ${ }^{6}$, Corinne A. Diggins $^{7}$
}

${ }^{1}$ US Geological Survey, Virginia Cooperative Fish and Wildlife Research Unit, Blacksburg, Virginia 24061, USA ${ }^{2}$ North Carolina Wildlife Resources Commission, Asheville, North Carolina 28803, USA ${ }^{3}$ US Forest Service Northern Research Station, Princeton, West Virginia 24740, USA

${ }^{4}$ Geospatial and Environmental Analysis, Virginia Tech, Blacksburg, Virginia 24061, USA ${ }^{5}$ US Fish and Wildlife Service, North Carolina Field Office, Raleigh, North Carolina 27606, USA

${ }^{6}$ Department of Biology and Marine Biology, University of North Carolina-Wilmington, Wilmington, North Carolina 28403, USA ${ }^{7}$ Department of Fisheries and Wildlife Conservation, Virginia Tech, Blacksburg, Virginia 24061, USA

\begin{abstract}
The Carolina northern flying squirrel Glaucomys sabrinus coloratus is an endangered subspecies that is restricted to high elevation forests in the southern Appalachian Mountains. Owing to rugged terrain and nocturnal habits, the subspecies' natural history, home range characteristics and habitat preferences are poorly known. We radio-tracked 3 female and 2 male Carolina northern flying squirrels during late winter through spring 2012 in the Pisgah National Forest, North Carolina, USA. Tracked squirrels used 13 yellow birch Betula alleghaniensis and 9 red spruce Picea rubens as diurnal dens. Ten of the yellow birch dens were in cavities, whereas the remainders were dreys. Conversely, 8 of the red spruce dens were dreys and one was in a cavity. Mean $( \pm$ SE) female 95 and $50 \%$ adaptive kernel home ranges were $6.50 \pm 2.19$ and $0.93 \pm$ $0.33 \mathrm{ha}$, respectively, whereas the corresponding values for males were $12.6 \pm 0.9$ and $1.45 \pm$ 0.1 ha, respectively. Squirrels used red spruce stands with canopies $>20 \mathrm{~m}$ more than expected based on availability at the landscape and home range scales. Results should be interpreted cautiously because of small sample sizes and seasonal observations; however, they provide evidence that although northern hardwoods such as yellow birch are an important den habitat component, mature red spruce-dominated habitats with complex structure provide foraging habitats and are also den habitat. Our findings support efforts to improve the structural condition of extant red spruce forests and/or increase red spruce acreage to potentially benefit Carolina northern flying squirrels.
\end{abstract}

KEY WORDS: Carolina northern flying squirrel $\cdot$ Habitat use $\cdot$ Home range $\cdot$ Red spruce Southern Appalachians

\section{INTRODUCTION}

Understanding habitat associations and use undoubtedly is among the most important aspects of wildlife research and management. For rare, threatened or endangered species, these types of data are crucial for conserving or actively managing habitat necessary for species survival and recovery. The endangered Carolina northern flying squirrel Glaucomys sabrinus coloratus (CNFS) is a disjunct subspecies that is known or believed to be present in 13 mountain peaks or ranges of the Blue Ridge Moun- 
tains in the southern Appalachians in western North Carolina, eastern Tennessee, and southwestern Virginia. A post-Pleistocene, boreal relict, the CNFS is primarily associated with mixed northern hardwoodred spruce Picea rubens, red spruce-Fraser fir Abies fraseri forested landscapes and in a few instances, northern hardwood-eastern hemlock Tsuga canadensis forests in the region above $1400 \mathrm{~m}$ above sea level (a.s.1.) (Reynolds et al. 1999, Ford et al. 2007b). The CNFS is an arboreal, cavity- or drey-nester (Ford et al. 2007b). Its diet consists of a variety of plant and animal matter, with a large component of hypogeal fungi consumed when foraging on the forest floor

Similar to the Virginia northern flying squirrel Glaucomys sabrinus fuscus from the Allegheny Mountain portion of the central Appalachians, the CNFS was listed as endangered by the US Fish and Wildlife Service in 1985 (US Fish and Wildlife Service 1990). Reasons for listing the CNFS included the paucity of records through the 1980s, the fragmented 'skyisland' nature of suitable high-elevation habitat, further reduction of preferred forest conditions following exploitative logging and subsequent burning in the late 19th and early to mid 20th century, high elevation forest health decline from insect pests and atmospheric deposition, and parasite-mediated competition by southern flying squirrels $G$. volans. The Virginia northern flying squirrel (VNFS) was delisted in 2013 (78 Federal Register 140220-14023). Delisting of VNFS occurred following several years of comprehensive natural history data collection, landscapelevel habitat assessments, indications of year-to-year site persistence and coordinated efforts to manage its habitat in the more expansive 500000 to 750000 ha of potential habitat across a gradient of conservation uses in West Virginia and northwestern Virginia (Ford et al. 2010).

CNFSs have also shown a consistent pattern of stable to slightly increasing occupancy in western North Carolina (Ford et al. 2012). Moreover, the CNFS faces fewer land management impacts with associated regulatory implications, i.e. ongoing forest management, commercial recreation development, surface mining and wind energy, as did the VNFS in the central Appalachians (Ford et al. 2007a). However, the small area of suitable forest habitats (<50 000 ha), lack of landscape-connected meta-populations (Kelly et al. 2013), greater severity of forest health threats (Weigl et al. 1992) and presumed habitat vulnerability to climate change (Weigl et al. 1992, Ford et al. 2007b, Weigl 2007) probably means that avoiding additional extirpations is the best outcome managers can expect for the CNFS. Invariably, this subspecies is destined to remain a 'conservation challenge' for natural resource managers in the southern Appalachians (Weigl 2007).

The CNFS has been the subject of limited radiotelemetry studies to assess subspecies home range size and den tree characteristics (Weigl \& Osgood 1974, Weigl et al. 1992, Hackett 2002, Hughes 2006). In general, for the Carolina subspecies, male home ranges are larger than female home ranges, inter-sex home ranges are smaller than those reported for the VNFS (Menzel et al. 2006b, Ford et al. 2007a) and inter-sex home ranges are larger than those from the Pacific Northwest, where northern flying squirrel habitat quality is believed to be optimal (Witt 1992, Martin \& Anthony 1999). For both Appalachian subspecies, cavities in a wide variety of hardwood species are used. However, yellow birch Betula alleghaniensis or American beech Fagus grandifolia trees or snags are often the overwhelming den site selection choice. Additionally, each will also use drey nests in conifers such as red spruce (Weigl \& Osgood 1974, Weigl et al. 1992, Hackett \& Pagels 2003, Menzel et al. 2004, Ford et al. 2007b). With the partial exception of Hackett's (2002) effort, examinations of nightly foraging habitat use by the CNFS have mostly been non-empirical, qualitative assessments and not based in the context of actual habitat use versus availability (Weigl \& Osgood 1974, Weigl et al. 1992, Hughes 2006). From observations in the Roan Mountain area along the North Carolina-Tennessee line, Weigl et al. (1992) suggested that the CNFS denned and foraged along the northern hardwood-red spruce ecotone. Similarly, in analyzing the vegetative characteristics from trapping and nest-box capture sites of both Appalachian northern flying squirrel subspecies in North Carolina, Virginia and West Virginia, Payne et al. (1989) found that many occupied sites contained an admixture of red spruce and yellow birch indicative of either the ecotone between red spruce forests and northern hardwood forests or mixed forests. In a subsequent reexamination of nest box sites in West Virginia, Ford et al. (2004) found that site occupancy increased where montane conifer, e.g. red spruce, importance values increased from mixed to pure conifer stands. In the Mount RogersWhitetop area in Virginia, high-use portions of CNFS home ranges contained more red spruce and had higher snag densities than did low-use portions (Hackett 2002). Similarly, Menzel et al. (2006b) and Ford et al. (2007a) found that VNFS radio-tracked in wholly red spruce-dominated forests as well as those radio-tracked in mixed landscapes tended to forage preferentially within stands dominated by red spruce. 
Uncertainty about foraging habitat preference is a significant data gap that needs to be overcome for successful conservation and management of the CNFS. For example, examining radio-telemetryderived foraging data relative to mapped forest types in the context of second- and third-order habitat selection (Johnson 1980) could facilitate the development and refinement of spatially explicit predictive habitat models based on resource selection functions. Accordingly, as interest in high elevation forest habitat enhancement or restoration increases in the southern Appalachians, as has occurred in the central Appalachians (Rentch et al. 2007, Nowacki \& Wendt 2010), a better understanding of CNFS habitat preferences can help prioritize where to increase high elevation forest patch size or connectivity through active forest management actions. Herein, we describe our opportunistic capture, radio-collaring and tracking of 5 endangered CNFS to determine den tree use, home range size and foraging habitat selection in a landscape dominated by high elevation red spruce and northern hardwood cover types representative of much of the presumed CNFS habitat in the southern Appalachians.

\section{MATERIALS AND METHODS}

\section{Study area}

We conducted our study from March to June 2012 in the Pisgah National Forest, Middle Prong Wilderness, in southern Haywood County, North Carolina, on the northwest slopes of Mount Hardy in the headwaters of Buckeye Creek, approximately $1.5 \mathrm{~km}$ west of the Blue Ridge Parkway. Located within the Balsam Mountains massif proper, the study site elevations ranged from approximately 1600 to $1800 \mathrm{~m}$ above sea level (a.s.l.) (Fig. 1). The area was highly disturbed from exploitative logging and periodic wildfire in the early 20th century, and evidence of past anthropogenic disturbances, i.e. abandoned railroad grades, was abundant throughout. The forests generally were dominated by (1) a dominant red spruce overstory with dense Fraser fir and rosebay rhododendron Rhododendron maximum mid- and understories, or (2) northern hardwood dominant types, some with some red spruce overstory stems and a more open understory of red spruce regeneration and rosebay rhododendron or (3) a pure northern

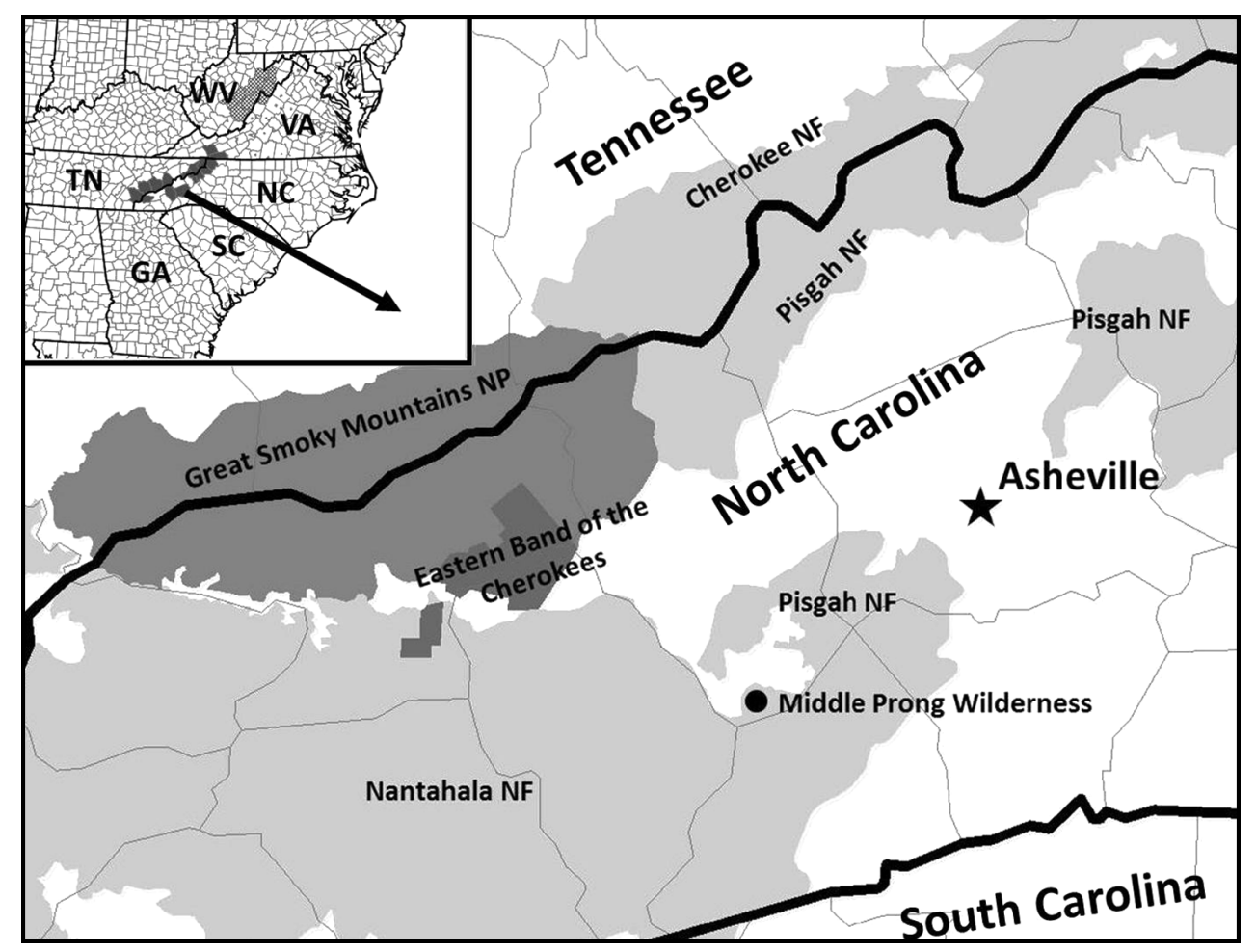

Fig. 1. Carolina northern flying squirrel Glaucomys sabrinus coloratus study site, Pisgah National Forest (NF), Middle Prong Wilderness, in the Balsam Mountains of western North Carolina, USA, March-May 2012. Inset shows the general distribution of the Carolina northern flying squirrel in western North Carolina, eastern Tennessee and southwestern Virginia, and the Virginia northern flying squirrel Glaucomys sabrinus fuscus in northwestern Virginia and east-central West Virginia. NP: National Park (different grey shading indicates different ownerships) 
hardwood comprised mostly of yellow birch and American beech with scattered understory patches of rhododendron or herbaceous flora. Several small oldfields with various amounts of shrubby woody invasion also occurred throughout. Data from the closest high elevation weather station (Waynesville $4.7 \mathrm{~W}$ ) and for western North Carolina in general indicated that March-June 2012 experienced near average precipitation but slightly warmer $\left(1.5-2.0^{\circ} \mathrm{C}\right)$ than normal temperatures (www.climate.gov/maps-data). Light snow cover occurred at the study site in early March. More detailed descriptions of the soils, geology and vegetation associations in the study area can be found in Schafale \& Weakley (1990), Odom \& McNab (2000) and Simon et al. (2005).

\section{Capture and tracking}

On 7 March 2013, we captured 5 adult CNFS (3 females and 2 males) in a nest box within a transect line that had been established in 1996 for longterm monitoring of the sub-species (McGrath \& Patch 2003). We removed each squirrel from the box and recorded sex, mass, hind foot length and reproductive condition. We differentiated CNFS from southern flying squirrels if hind foot measurements exceeded $34 \mathrm{~mm}$ and ventral fur was lead-colored at the base of the hair shaft (Wells-Gosling \& Heaney 1984, Ford et al. 2007a). We attached uniquely numbered Monel No. 1 ear tags (National Band and Tag Co.) and $2.1 \mathrm{~g}$ Holohil BD-2C radio-transmitter collars to each individual. Following transmitter attachment, we placed each squirrel back in the nest box and re-positioned the box on the tree. Capture and handling of CNFS was approved by Virginia Tech Institutional Care and Use Committee protocol 11120-FIW and US Fish and Wildlife Service Native Endangered Species Permit TE34778A-0.

We used Wildlife Materials TR4-2000S receivers and 2-element folding yagi antennas to track radiocollared CNFS to determine home range, foraging habitat selection and den-tree selection. Prior to the 8 evening tracking sessions (8 March to 10 May 2013), we located the den trees containing each radio-collared squirrel. For each den tree, we recorded tree species, status (live or snag), position and condition (overstory or midstory, dominant or suppressed), diameter at breast height (DBH) and den type (cavity or drey). Our tracking efforts to determine home range and habitat use began shortly after sunset and ceased when squirrel movements ended, typically before or near midnight. We obtained telemetry loca- tions using 2 fixed-station bi-angulation bearings with readings taken simultaneously to minimize temporal error (Schmutz \& White 1990). Telemetry stations were located $>50 \mathrm{~m}$ apart to ensure that bearings would be as close to a $90^{\circ}$ angle as possible (White 1985). We took bearings for each squirrel at intervals of 10 to $16 \mathrm{~min}$ to minimize spatial autocorrelation between successive points for each individual animal (White \& Garrot 1990, Menzel et al. 2006b).

\section{Home range and habitat use analyses}

We entered UTM coordinates of den trees, telemetry stations and bi-angulation bearings from nightly foraging into LOCATE II software (Pacer Co.) to obtain UTM coordinates of radio-collared CNFS. Although error polygon estimation is not possible with biangulated points (Reding et al. 2013), to reduce possible inaccuracy, we censored points formed from angles of $<20^{\circ}$ and $>160^{\circ}$ (Gese et al. 1988). To calculate $95 \%$ (overall) and $50 \%$ (core-foraging) adaptive kernel home range estimates, we imported UTM coordinates into the Animal Movement Analysis Extension (Hooge \& Eichenlaub 2000) using ArcView 3.2 Geographic Information System (ESRI) to create individual squirrel home range shapefiles. We then overlaid these home range estimator shapefiles and the original telemetry points on cover type layers generated by hierarchical feature extractions of North Carolina 1-m resolution color-infrared digital orthophoto quarter-quadrangles from 1998 (www. nconemap.com) using the Feature Analyst Extension 4.2.0.11 (2008 Visual Learning Systems) in ArcMap 9.3.1 Geographic Information System (1999-2009 ESRI) for the area within a $1000 \mathrm{~m}$ radius of a combined home range polygon. Our final overall habitat types were simply classified as red spruce-dominant overstory forest, northern hardwood-dominant overstory forest or oldfield/shrub-scrub habitat. Due to the use of high-resolution imagery, a simple 3-category classification scheme and the authors' familiarity with the study site, we did not conduct a quantitative validation of the classified data, nor do we believe there have been substantive vegetation composition changes since 1998 in the Middle Prong Wilderness because no active management has occurred therein since Congressional designation in 1984, and impacts since have been limited primarily to dispersed recreation, i.e. hiking, hunting and camping. We further divided red spruce and northern hardwood forest types into structurally 'mature' 
or 'mid-successional' categories by combining our vegetation classifications developed by hierarchical features extraction with forest canopy height values derived from $22.8 \mathrm{~cm}$ vertical resolution LiDAR (light intensity and data ranging; Newcomb 2012). Mature forests were defined as those with canopy heights $>20 \mathrm{~m}$, or $2 / 3$ the minimum height value observed in uncut, old-growth red spruce forests in the southern Appalachians (Minckler 1945), whereas mid-successional forests were those with canopy heights $\leq 20 \mathrm{~m}$.

CNFS habitat use is well understood at the firstorder level of selection as high elevation areas in the southern Appalachians (Johnson 1980, Ford et al. 2007a). Thus, we examined (1) second-order 'home range selection within the landscape' habitat use within the area defined in our supervised vegetation classification surrounding and including $95 \%$ adaptive kernel home ranges and (2) third-order 'within home range selection' habitat use for both the $95 \%$ adaptive kernels and the core-use $50 \%$ adaptive kernel home ranges. For second- and third-order examinations of all squirrel telemetry points combined, we used Program BIOTAS (Ecological Software Solutions) to calculate habitat selection or avoidance using chi-square analysis and associated Bonferroni $z$-statistic confidence intervals on the proportion of each habitat type observed in the study area versus the proportion of total habitat area as described by Neu et al. (1974). We retained den trees and foraging points in the same analyses because previous assessments of CNFS and VNFS occupancy and habitat use have shown that foraging habitat is dependent upon proximity to, and quality of, denning habitat (Hughes 2006, Ford et al. 2007a, 2010).

\section{RESULTS}

\section{Den trees}

From March to May, we were able to obtain 317 usable foraging and den-tree points for the 3 female and 2 male CNFS we had radio-collared. We documented 22 diurnal den trees. Thirteen of the dens occurred in yellow birch, all but one of which were midstory or suppressed overstory trees. Average DBH for yellow birch den-trees was $26.18 \pm 2.07 \mathrm{~cm}$ (mean $\pm \mathrm{SE}$ ). Ten of the yellow birch tree dens were located in cavities and 3 were drey nests. The remaining 9 dens were found in red spruce. Average DBH for red spruce den-trees was $49.33 \pm 4.89 \mathrm{~cm}$. Eight of the red spruce dens occurred in dreys whereas only one red spruce den was found in a cav- ity. All of the red spruce den-trees were overstory canopy dominant or co-dominant stems. Following our capture of these 5 squirrels, we recorded 10 instances of den-sharing with 6 instances of femalefemale sharing and 4 instances of male-female sharing. The 2 males never shared a den following their capture in the same nest box.

\section{Home range and habitat use}

Mean female 95 and $50 \%$ adaptive kernel home ranges were $6.50 \pm 2.19$ and $0.93 \pm 0.33 \mathrm{ha}$, respectively ( $\mathrm{n}=3$ for each; Fig. 2). Mean male 95 and $50 \%$ adaptive kernel home ranges were $12.6 \pm 0.9$ and $1.45 \pm 0.1 \mathrm{ha}$, respectively ( $\mathrm{n}=2$ for each). At the $2 \mathrm{nd}$ order of selection, habitat use was not proportional to availability in the buffered $95 \%$ adaptive kernel

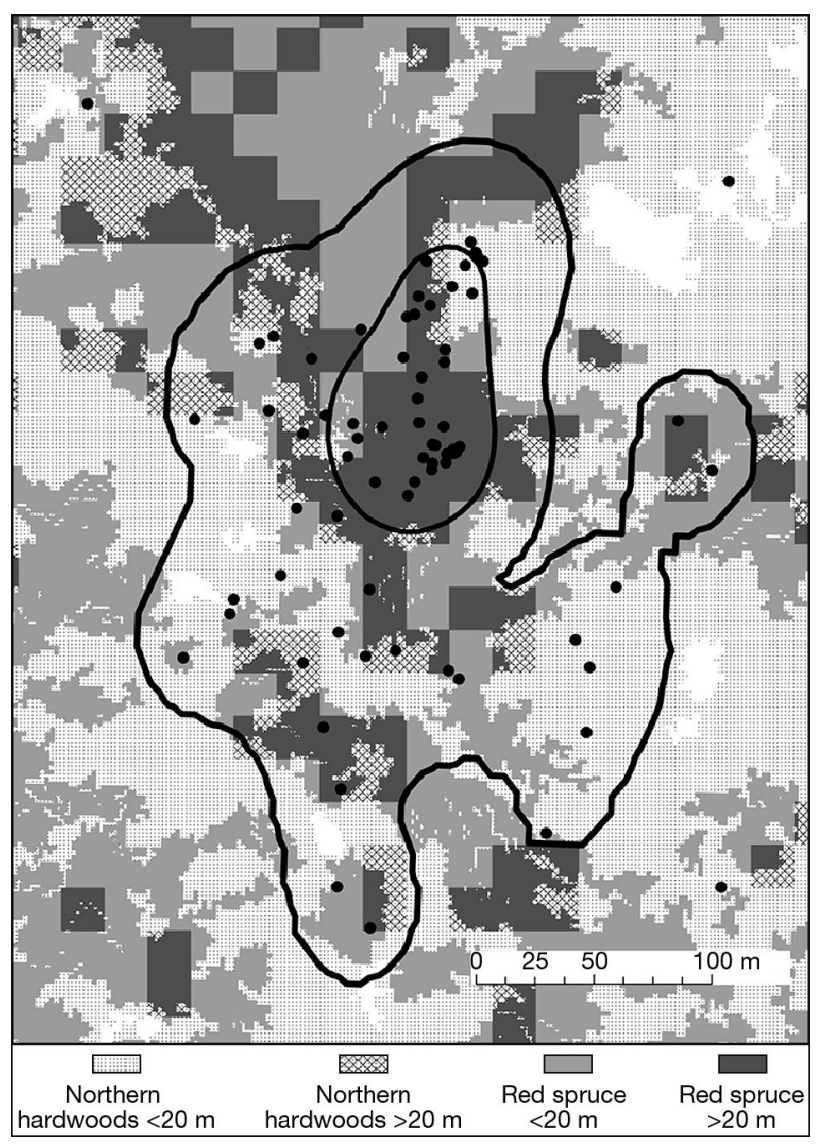

Fig. 2. Example female Carolina northern flying squirrel Glaucomys sabrinus coloratus $95 \%$ adaptive kernel (outer isopleth) and $50 \%$ adaptive kernel (inner isopleth) home ranges in the Balsam Mountains of western North Carolina, March-May 2012. Vegetation forms and canopy height are shown in the key; white areas are oldfield communities; filled circles represent squirrel telemetry fixes. See 'Materials and methods' for complete description 
home ranges $\left(\chi^{2}=82.15\right.$, df $\left.=4, \mathrm{p}<0.001\right)$, with mature red spruce used more than expected $\left(\rho_{\text {io }}=\right.$ 0.17, $\rho_{i}=0.24$ to 0.38 ; Fig. 3) and mature northern hardwoods used less than expected $\left(\rho_{\text {io }}=0.25, \rho_{\mathrm{i}}=\right.$ 0.05 to 0.14 ; Fig. 3 ), where $\rho_{\text {io }}$ is the expected observation value if squirrels occurred in each habitat in exact proportion to availability and $\rho_{i}$ is the theoretical proportion of occurrence. All other habitats were

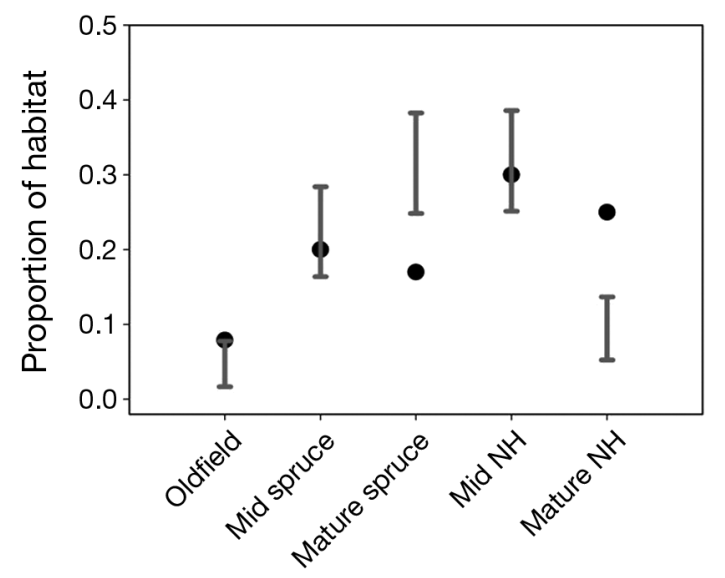

Fig. 3. Carolina northern flying squirrel Glaucomys sabrinus coloratus second-order habitat selection in the Balsam Mountains of western North Carolina, March-May 2012. Filled circles represent observed habitat proportions. Error bars below signify habitat use less than expected based on availability, error bars above signify habitat use greater than expected based on availability, and overlapping error bars signify habitat use proportional to availability. NH: northern hardwood; mid: $<20$ m canopy height; mature: $>20 \mathrm{~m}$ canopy height

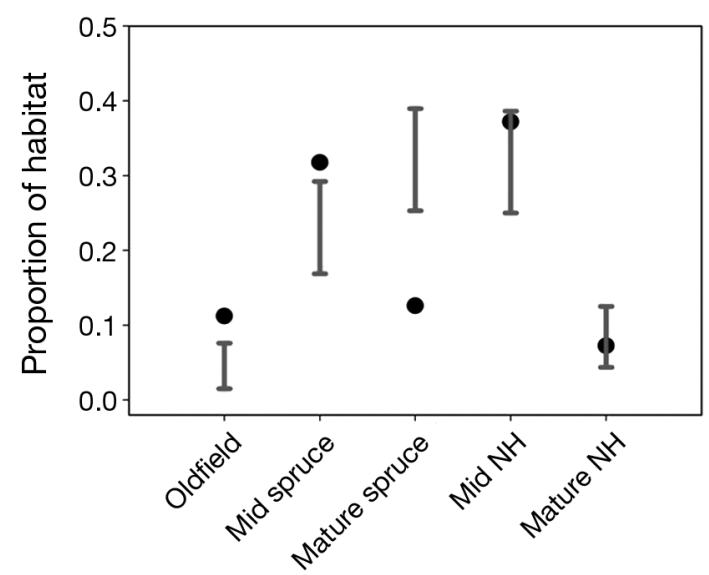

Fig. 4. Carolina northern flying squirrel Glaucomys sabrinus coloratus third-order habitat selection within $95 \%$ adaptive kernel home ranges in the Balsam Mountains of western North Carolina, March-May 2012. Filled circles represent observed habitat proportions. Error bars below signify habitat use less than expected based on availability, error bars above signify habitat use greater than expected based on availability, and overlapping error bars signify habitat use proportional to availability. NH: northern hardwood; mid:

$<20$ m canopy height; mature: $>20$ m canopy height used in proportion to their availability (Fig. 3). At the 3rd order of selection relative to the $95 \%$ adaptive kernel home range, habitat use was not proportional to availability $\left(\chi^{2}=90.36\right.$, $\left.\mathrm{df}=4, \mathrm{p}<0.001\right)$, with mature red spruce used more than expected $\left(\rho_{\text {io }}=\right.$ 0.13, $\rho_{i}=0.25$ to 0.39; Fig. 4) and 2 habitats used less than expected: mid-successional red spruce $\left(\rho_{\text {io }}=\right.$ 0.32, $\rho_{\mathrm{i}}=0.17$ to 0.29 ; Fig. 4 ) and oldfields ( $\rho_{\text {io }}=0.11$, $\rho_{\mathrm{i}}=0.02$ to 0.08 ; Fig. 4). All other habitats were used in proportion to their availability (Fig. 4). At the 3rd order of selection relative to the $50 \%$ adaptive kernel home range, habitat use was not proportional to availability $\left(\chi^{2}=144.48, \mathrm{df}=4, \mathrm{p}<0.001\right)$, with mature red spruce used more than expected ( $\rho_{\text {io }}=0.13$, $\rho_{\mathrm{i}}=0.35$ to 0.54 ; Fig. 5) and 2 habitats were used less than expected: mid-successional red spruce $\left(\rho_{\text {io }}=\right.$ $0.32, \rho_{\mathrm{i}}=0.11$ to 0.25 ; Fig. 5 ) and oldfields $\left(\rho_{\mathrm{io}}=0.11\right.$, $\rho_{i}=0$ to 0.03 ; Fig. 5). All other habitats were used in proportion to their availability (Fig. 5).

\section{DISCUSSION}

\section{Response to extant forest condition}

Overall, the home ranges we report for CNFS were consistent with other late winter-early spring values (a time when breeding-male movements are greatest) that have been reported in the red sprucenorthern hardwood ecotone to the north in the Roan

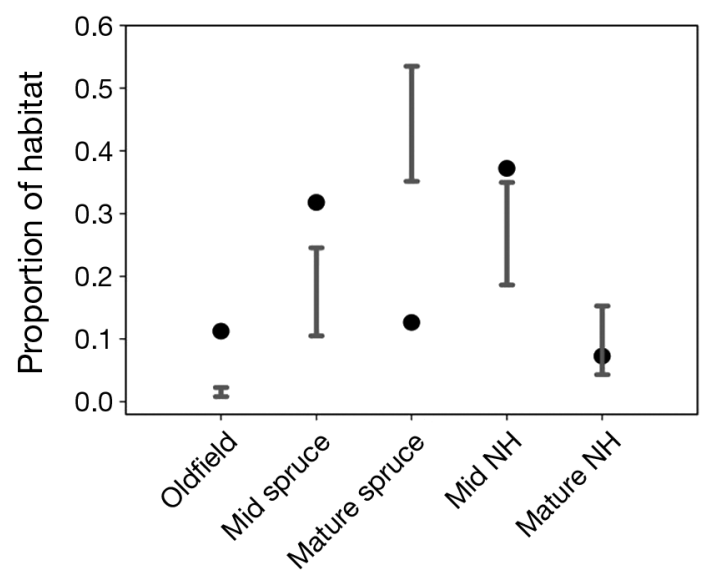

Fig. 5. Carolina northern flying squirrel Glaucomys sabrinus coloratus third-order habitat selection within $50 \%$ adaptive kernel home ranges in the Balsam Mountains of western North Carolina, March-May 2012. Filled circles represent observed habitat proportions. Error bars below signify habitat use less than expected based on availability, error bars above signify habitat use greater than expected based on availability, and overlapping error bars signify habitat use proportional to availability. NH: northern hardwood; mid: $<20$ m canopy height; Mature: >20 m canopy height 
Mountain area (Weigl et al. 1992) or in northern hardwood-eastern hemlock communities to the south in the Unicoi Mountains (Hughes 2006). Conversely, the home ranges we observed are much smaller than those from across a gradient of pure northern hardwoods, mixed red spruce-northern hardwoods to primarily conifer-dominated forests during the summer months for the VNFS in the central Appalachians of West Virginia. This difference might be suggestive of a better high-elevation forest habitat quality in our study area in the southern Appalachians than that in the central Appalachians. The cumulative impact of exploitative forest harvesting and subsequent wildfire probably was more intense and continued to occur later in the 20th century across the entire landscape in the central Appalachians than in the southern Appalachians (Korstian 1937, Pyle \& Schafale 1988). For both northern flying squirrel subspecies dependent upon a minimum threshold of boreal conifer composition in conjunction with structural complexity/forest decadency, time since cessation of stand-level disturbance is responsible for a legacy impact relative to the extant habitat conditions.

The proportion of den-tree species and nest-type split between primarily cavities in yellow birch and dreys in red spruce also is similar to what has been reported elsewhere from North Carolina (Weigl et al. 1992) and the Mount Rogers-Whitetop area of southwest Virginia (Hackett \& Pagels 2003) for CNFS, as well as for VNFS in West Virginia (Odom et al. 2001, Menzel et al. 2004, Ford et al. 2007a). Although an observation generally limited by the lack of northern flying squirrels radio-tagged simultaneously in the same local area of either subspecies, the rates of den-sharing by the squirrels we observed were consistent with those in the Roan Mountain area (Weigl \& Osgood 1974, Weigl et al. 1992). From the perspective of forest habitat, this den-use congruence over the wider central and southern Appalachian region is partial evidence that CNFS and VNFS will readily use a hardwood component for den habitat when available. Additionally, it demonstrates that past disturbance history and current forest structure aside, some components of forest composition or structure in terms of den availability probably are more similar than not, despite differences in stand reestablishment processes and timing. However, most CNFS and VNFS tracked by researchers over the past 2 decades have been caught and followed near distinct red spruce-northern hardwood ecotones (Weigl et al. 1992) or in local landscapes dominated by forests with a mixed northern hardwood and red spruce dominance, due in large part to where nest-box survey lines have been estab- lished (Urban 1988, Hackett \& Pagels 2003, Menzel et al. 2004), but see Hughes (2006) and Ford et al. (2007a) for either wholly northern hardwood-dominant or wholly red spruce-dominant den site observations, respectively.

Despite the limitations of a very small sample size from within a narrow temporal window further biased by the probable mother-offspring/sibling relation of the squirrels, our study is differentiated from the previous radio-telemetry studies of CNFS by our quantitative examination of habitat-type use surrounding and including the home range in a manner similar to Menzel et al. (2006b) and Ford et al. (2007a) in West Virginia for the VNFS. Hackett (2002) noted that CNFS high-use areas were associated with mature red spruce, presumably for foraging, and yellow birch snags, presumably for denning. However, habitatuse metrics were not derived explicitly from foraging points nor were data placed in the context of measured habitat availability, thereby limiting causal linkage inferences. At all scales of habitat selection, the CNFS we observed preferentially foraged in mature red spruce-dominated stands that also contained abundant understory Fraser fir and red spruce advance regeneration, as well as considerable rosebay rhododendron shrub cover.

\section{Importance of red spruce}

Weigl (2007) suggests that CNFS are tied to the ecotone between northern hardwoods and red sprucedominated stands. However, the ability of CNFS to use drey nests in red spruce in our study and others (Weigl \& Osgood 1974, Hackett \& Pagels 2003), the overall foraging habitat selection for red sprucedominated forests for VNFS (Menzel et al. 2006b, Ford et al. 2007a) and the foraging selection for red spruce at all scales herein may suggest instead that CNFS may prefer forest stands with a substantial (to majority) red spruce component rather than along a 'hard' ecotone setting, where northern hardwood and red spruce stands are adjacent but distinct in composition. At the landscape level, Ford et al. (2004) and Menzel et al. (2006a) noted that the probability of occurrence of VNFS increases with the amount of red spruce in the forest overstory. Ford et al. (2010) showed that annual measures of occupancy $(\Psi)$ by females (suggesting persistence was higher) in nestbox lines where red spruce dominance was higher $(\Psi=0.95)$ than in northern hardwoods without a red spruce component $(\Psi=0.5)$. Similarly, annual occupancy for CNFS at nest box lines appears to be posi- 
tively related to decreasing distance to red spruce or mixed red spruce-northern hardwood stands in North Carolina (Ford et al. 2012). For VNFS, generally the greater the relative amount of red spruce or exotic Norway spruce Picea abies within a squirrel's home range, the smaller that home range was, suggesting that habitat quality increases with increasing amounts of spruce (Menzel et al. 2006b, J. Menzel unpubl. data).

Our work adds additional clarity to the ecology of the northern flying squirrel in the Appalachians by quantitatively linking it to older, more mature forest conditions for which we believed red spruce height served as a suitable surrogate. Loeb et al. (2000) observed that the hypogeal fungi important to CNFS were more abundant in association with red spruce than northern hardwoods in the southern Appalachians. Stands with a conifer component may offer more protective cover from predators for foraging CNFS than those without. The link between forest maturity or forest decadence, indicative of old-growth conditions that support diverse and abundant fungal communities, and optimal foraging and den conditions for northern flying squirrels has long been noted in the Pacific Northwest and southeast Alaska (Carey et al. 1999, Smith 2007). Unfortunately, outside of a few areas in the Great Smoky Mountains National Park where substantive old-growth, high-elevation forest conditions and CNFS occur together, these conditions largely are absent at the landscape level in the remainder of the southern Appalachians or in the central Appalachians for VNFS.

Nonetheless, it would be premature to totally discount the value of northern hardwoods to CNFS. Concomitant with the findings of Hughes (2006), we recognize that CNFS can occur in the absence or significant presence of the red spruce or red spruceFraser fir community in the southern Appalachians. Indeed, recent surveys using acoustics and cameratrapping suggest that populations of CNFS may also occur in North Carolina on Big Bald (Madison County), Pond Mountain and Sugar Mountain (Avery County), where virtually no extant red spruce remains (C. A. Kelly unpubl. data). Northern hardwood tree species such as yellow birch often constitute the most used denning substrate in occupied habitat (Weigl et al. 1992, Hughes 2006), and we clearly observed use of northern hardwood forests at varying scales proportional to their availability. Still, it should be noted that even in the Unicoi Mountains, where CNFS occur without red spruce, their presence and habitat use is linked to forest stands with a significant eastern hemlock component or other macro- and micro-habitat conditions such as forest decadence, abundant coarse woody debris and a rich herb or shrub strata. We concur with Weigl (2007) that many of the direct causal relationships between required habitat components and the presence of both CNFS and VNFS remain poorly elucidated. Accordingly, we believe the weight of evidence from this study and that of preceding research does suggest that both CNFS and VNFS foraging habitat use is linked to red spruce occurrence and abundance (Hackett 2002, Menzel et al. 2006b, Ford et al. 2007a), and that overall squirrel occurrence and occupancy are higher with an increasing red spruce component at the forest stand and landscape scales (Ford et al. 2004, 2010, 2012, Menzel et al. 2006a).

\section{Management implications}

Adaptive management discussions and efforts to increase the red spruce component in the southern and central Appalachians to benefit CNFS and VNFS (Schuler et al. 2002, Rentch et al. 2007) have been appropriately questioned owing to the untested nature of the concepts (Weigl 2007). However, it has been well documented that the area dominated by red spruce, and presumably the area of mixed red spruce-northern hardwood forests, is greatly reduced relative to pre-European settlement and prior to forest exploitation (White et al. 2012). Mast production from beechnuts and maple samaras in northern hardwood stands in some years is not dissimilar to caloric values reported from oak-dominated stands (Jensen et al. 2012) that are capable of supporting the southern flying squirrel, a competitor of the CNFS. Therefore it would seem reasonable that efforts to promote and increase red spruce should benefit both subspecies of northern flying squirrels in the Appalachians (and possibly decrease suitability for southern flying squirrels) as well as potentially increase this vulnerable forest type's resilience to perturbations such as ongoing climate change (Nowacki et al. 2010, White et al. 2012). Few forest stands outside of the very highest elevations of the southern Appalachians (>1900 m) are devoid of any hardwood species at the local scale. Therefore, it is doubtful that such efforts would eliminate potential den sites to an extent greater than the increased benefit of the creation of better foraging habitat, particularly at the small scales that might be feasible in a restoration context and where important hardwoods such as yellow birch could be targeted for retention. Additionally, in the context of CNFS, the ecological definition and 
spatial distinction between mixed red spruce-northern hardwood forests and the red spruce-northern hardwood ecotone has remained empirically 'fuzzy' and needs to be clarified for consistency in use relative to CNFS. Efforts to better document the local distribution and abundance of CNFS in the southern Appalachians across the complete gradient of elevations and forest types without any significant presence of montane conifer or pure red spruce-Fraser fir at elevations precluding significant hardwood presence, i.e. northern hardwood forests, are much needed.

Acknowledgements. Funding for our study was provided by the US Fish and Wildlife Service Region 4, Asheville, North Carolina Field Office, US Geological Survey Cooperative Research Units program, North Carolina Wildlife Resources Commission, and Virginia Department of Game and Inland Fisheries. Field assistance was provided by D. Brown and S. Sweeten. We especially thank S. Cameron and K. Weeks for their programmatic support. The use of any trade, product or firm names does not imply endorsement by the US Government.

\section{LITERATURE CITED}

Carey AB, Kershner J, Biswell B, de Toledo LD (1999) Ecological scale and forest development: squirrels, dietary fungi, and vascular plants in managed and unmanaged forests. Wildl Monogr 142:1-71

Ford WM, Stephenson SL, Menzel JM, Black DR, Edwards JW (2004) Habitat characteristics of the endangered Virginia northern flying squirrel (Glaucomys sabrinus fuscus) in the Central Appalachians. Am Midl Nat 152: 430-438

Ford WM, Mertz KN, Menzel JM, Sturm KK (2007a) Winter home range and habitat use of the Virginia northern flying squirrel (Glaucomys sabrinus fuscus). USDA Forest Service Res Pap NRS-4. Northern Research Station, Newtown Square, PA

Ford WM, Rodrigue JL, Chapman BR (2007b) Northern flying squirrel. In: Trani-Griep M, Ford WM, Chapman BR (eds) Land manager's guide to mammals of the South. The Nature Conservancy, Durham, NC, p 389-394

Ford WM, Moseley KR, Stihler CW, Edwards JW (2010) Area occupancy and detection probabilities of the Virginia northern flying squirrel (Glaucomys sabrinus fuscus) using nest-box surveys. In: Rentch JS, Schuler TM (eds) Proceedings from the Conference on the Ecology and Management of High Elevation Forests in the Central and Southern Appalachian Mountains. USDA Forest Service Gen Tech Rep NRS-P-64. Northern Research Station, Newtown Square, PA, p 37-47

Ford WM, Evans A, Odom RH (2012) Preliminary application of occupancy modeling (Program Presence) for Carolina northern flying squirrels. Report to North Carolina Wildlife Resources Commission, Asheville, NC

Gese EM, Rongstad OJ, Mytton WF (1988) Home-range and habitat use of coyotes in southeastern Colorado. J Wildl Manag 52:640-646
Hackett HM (2002) Characteristics of the endangered northern flying squirrel (Glaucomys sabrinus coloratus) in southwest Virginia. MS thesis, Virginia Commonwealth University, Richmond, VA

> Hackett HM, Pagels JF (2003) Nest site characteristics of the endangered northern flying squirrel (Glaucomys sabrinus coloratus) in southwest Virginia. Am Midl Nat 150: 321-331

Hooge PN, Eichenlaub B (2000) Animal movement extension to ArcView. Version 2.0. US Geological Survey, Anchorage, AK. www.absc.usgs.gov/glba/gistools/animal _mvmt.htm

Hughes RS (2006) Home ranges of the endangered Carolina northern flying squirrel in the Unicoi Mountains of North Carolina. Proc Southeast Assoc Fish Wildl Agenc 60: $19-24$

> Jensen PG, Demers CL, McNulty SA, Jakubas WJ, Humphries MM (2012) Marten and fisher responses to fluctuations in prey populations and mast crops in the northern hardwood forest. J Wildl Manag 76:489-502

Johnson DH (1980) The comparison of usage and availability measurements for evaluating resource preference. Ecology 61:65-71

Kelly CA, Diggins CA, Lawrence AJ (2013) Crossing structures reconnect federally endangered flying squirrel populations divided for 20 years by road barrier. Wildl Soc Bull 37:375-379

> Korstian CF (1937) Perpetuation of spruce on cut-over and burned lands in the higher southern Appalachian Mountains. Ecol Monogr 7:125-167

Loeb SC, Tainter FH, Cazares E (2000) Habitat associations of hypogeous fungi in the southern Appalachians: implications of the endangered Carolina northern flying squirrel (Glaucomys sabrinus fuscus). Am Midl Nat 144: 286-296

Martin KJ, Anthony RJ (1999) Movements of northern flying squirrels in different-aged forest stands of western Oregon. Am Midl Nat 144:286-296

McGrath C, Patch S (2003) Using a terrain-based vegetation model to map Carolina northern flying squirrel distribution. Proc Southeast Assoc Fish Wildl Agenc 57:243-251

Menzel JM, Ford WM, Edwards JW, Menzel MA (2004) Nest tree use by the endangered Virginia northern flying squirrel with recommendations for habitat restoration. Am Midl Nat 151:355-368

Menzel JM, Ford WM, Edwards JW, Ceperley L (2006a) A habitat model for the Virginia northern flying squirrel (Glaucomys sabrinus fuscus) in the central Appalachian Mountains. USDA Forest Service Res Pap NE-729. Northeastern Research Station, Newtown Square, PA

> Menzel JM, Ford WM, Edwards JW, Terry TM (2006b) Home range and habitat use of the vulnerable Virginia northern flying squirrel Glaucomys sabrinus fuscus in the central Appalachian Mountains. Oryx 40:204-210

Minckler LS (1945) Reforestation in the spruce type in the southern Appalachians. J For 43:349-356

Neu CW, Byers CR, Peek JM (1974) A technique for analysis of utilization-availability data. J Wildl Manag 38:541-545

Newcomb D (2012) Using GRASS GIS to model solar irradiation on North Carolina aquatic habitats with canopy data. Trans GIS 16:161-176

Nowacki G, Wendt D (2010) The current distribution, predictive modeling, and restoration potential of red spruce in West Virginia. In: Rentch JS, Schuler TM (eds) Proceedings from the Conference on the Ecology and Man- 
agement of High Elevation Forests in the Central and Southern Appalachian Mountains. USDA Forest Service Gen Tech Rep NRS-P-64. Northern Research Station, Newtown Square, PA, p 163-178

Nowacki G, Carr R, Van Dyck M (2010) The current status of red spruce in the eastern United States: distribution, population trends, and environmental drivers. In: Rentch JS, Schuler TM (eds) Proceedings from the Conference on the Ecology and Management of High Elevation Forests in the Central and Southern Appalachian Mountains. USDA Forest Service Gen Tech Rep NRS-P-64. Northern Research Station, Newtown Square, PA, p 140-162

Odom RH, McNab WH (2000) Using digital terrain modeling to predict ecological types in the Balsam Mountains of western North Carolina. USDA Forest Service Res Note SE-8, Southern Research Station, Asheville, NC

Odom RH, Ford WM, Edwards JW, Stihler CW, Menzel JM (2001) Developing a habitat model for the endangered Virginia northern flying squirrel (Glaucomys sabrinus fuscus) in the Allegheny Mountains of West Virginia. Biol Control 99:245-252

Payne JL, Young DR, Pagels JF (1989) Plant community characteristics associated with the endangered northern flying squirrel, Glaucomys sabrinus, in the southern Appalachians. Am Midl Nat 121:285-292

Pyle C, Schafale MP (1988) Land use history of three sprucefir forest sites in southern Appalachia. J Forest Hist 32: $4-21$

Reding DM, Cushman SA, Gosselink TE, Clark WK (2013) Linking movement behavior and fine-scale genetic structure to model landscape connectivity for bobcats (Lynx rufus). Landscape Ecol 28:471-485

Rentch JS, Schuler TM, Ford WM, Nowacki GJ (2007) Red spruce stand dynamics, simulations and restoration opportunities in the central Appalachians. Restor Ecol 15:440-452

Reynolds RJ, Pagels JF, Fies ML (1999) Demography of northern flying squirrels in Virginia. Proc Southeast Assoc Fish Wildl Agenc 53:340-349

Schafale MP, Weakley AS (1990) Classification of the natural communities of North Carolina, third approximation. North Carolina Department of Environment, Health, and Natural Resources, Division of Parks and Recreation, Natural Heritage Program, Raleigh, NC

Schmutz JA, White GC (1990) Error in telemetry studies:

Editorial responsibility: Kartik Shanker,

Bangalore, India effect of animal movement on triangulation. J Wildl Manag 54:506-510

Schuler TM, Ford WM, Collins RJ (2002) Successional dynamics and restoration implications of a montane coniferous forest in the central Appalachians. Nat Areas J 22:88-98

Simon SA, Collins TK, Kauffman GL, McNab WH, Ulrey CJ (2005) Ecological zones in the southern Appalachians: first approximation. USDA Forest Service Res Pap SRS41. Southern Research Station, Asheville, NC

Smith WP (2007) Ecology of Glaucomys sabrinus: habitat, demography and community relations. J Mammal 88: 862-881

Urban V (1988) Home range, habitat utilization and activity of the endangered northern flying squirrel. MS thesis, West Virginia University, Morgantown, WV

US Fish and Wildlife Service (1990) Appalachian northern flying squirrel (Glaucomys sabrinus fuscus and Glaucomys sabrinus coloratus) recovery plan. USDI Fish and Wildlife Service, Newton Corner, MA

Weigl PD (2007) The northern flying squirrel Glaucomys sabrinus: a conservation challenge. J Mammal 88: 897-907

Weigl PD, Osgood DW (1974) Study of the northern flying squirrel, Glaucomys sabrinus by temperature telemetry. Am Midl Nat 92:482-486

Weigl PD, Knowles TW, Boynton AC (1992) The distribution and ecology of the northern flying squirrel, Glaucomys sabrinus coloratus, in the southern Appalachians. North Carolina Wildlife Resources Commission Project Report Raleigh, NC

Wells-Gosling N, Heaney LR (1984) Glaucomys sabrinus. Mamm Species 229:1-8

White GC (1985) Optimal locations of towers for triangulation studies using biotelemetry. J Wildl Manag 49: 190-196

White GC, Garrot RA (1990) Analysis of wildlife radio-tracking data. Academic Press, New York, NY

White PB, van de Gevel SL, Soulé PT (2012) Succession and disturbance in an endangered red spruce-Fraser fir forest in the southern Appalachian Mountains, North Carolina, USA. Endang Species Res 18:17-25

> Witt JW (1992) Home range and density estimates for the northern flying squirrel, Glaucomys sabrinus, in western Oregon. J Mammal 73:921-929

Submitted: June 2, 2013; Accepted: October 23, 2013 Proofs received from author(s): January 14, 2014 